\title{
ТЕРМИНОЛОГИЧНИ ПРЕДИЗВИКАТЕЛСТВА ПРИ ИЗСЛЕДВАНЕТО НА АПОЗИТИВНАТА КОНСТРУКЦИЯ
}

\author{
Антон Гецов, Силвия Великова \\ TERMINOLOGICAL CHALLENGES IN THE STUDY OF THE APPOSITIONAL \\ CONSTRUCTION \\ Anton Getsov, Silvia Velikova
}

\begin{abstract}
This article examines the use of key terms in research publications in the field of syntax which focus on the linguistic status, the specific features, and the typology and realisations of appositive constructions. The main focus of analysis is on the inconsistent, unacceptable and unjustified use of key terms, such as „,apposition“, „appositive“, „,appositivity“, ,appositional“, and their derivatives and word-combinations of a terminological nature. The arbitrary mixing and replacement of these terms could cause significant problems related to the presentation and reception of the texts in which they are used and the authors' intention. The study also systematizes and summarizes the dominant meanings of the fundamental terms and analyzes some debatable solutions in regard to their use in linguistic studies in several foreign languages.
\end{abstract}

Key words: metalanguage, terminology, apposition, appositive, appositive relation, appositive (appositional) construction.

DOI: https://doi.org/10.46687/DFTH4492

\section{Въведение: метаезикови и терминологични проблеми в лингвистичните изследвания}

Метаезикът, чрез който се описва и се анализира естественият език, изпълнява сьществена функция в лингвистичната наука. Той е уникално средство за комуникация и напълно се различава от езика-обект или от естествения език, който описва (Lyons 1977: 11). Метаезиковата функция е „свойството, което прави възможно използването на даден език, за да се отнася към себе си (изцяло или частично)“; то се нарича „рефлексивност“ (Lyons 1995: 7). Взаимодействието между езика-обект и метаезика може да се осъществява в рамките на един език или да е междуезиково. Така например два езика могат да бъдат в „обектноезиково - метаезиково отношение“, ако езиковите явления от единия език се анализират чрез другия език, както е при описанието на немската граматика на английски език (Bussmann 2006: 823). В лингвистичната 
наука е много важно комуникацията да се осъществява чрез посредничеството на „общ метаезик“, без значение дали лингвистите обменят идеите си в един езиков контекст (например на техния собствен език), или - на различни езици (при превод или описание на изследванията на друг език). Следователно основната функция на метаезика е двуизмерна. Първо, той служи като индикатор на теоретичната и методологическата основа на дадена научна разработка. Ако нейният метаезик е непрецизен и непоследователен, теоретичните принципи, въплътени в изследването, изглеждат противоречиви и объркващи. Второ, метаезикът има функция на медиатор или на средство за предаване на ясни и недвусмислени значения и идеи в академичния диалог между лингвистите, изследващи определени езикови явления.

Въпреки че терминологията и метаезикът са две различни понятия, терминологията (считана за лексикалния аспект на метаезика, или техническата лексика) има определяща роля за коректността и яснотата на металингвистичния код. Не е изненадващ фактът, че интересът към терминологичните единици е изкристализирал в интердисциплинарна научна област, която изследва термините и техните функции едновременно като ,езикови единици (лингвистика), като когнитивни елементи (логика и онтология, т.е. като част от когнитивната наука) и като комуникативни средства (теория на комуникацията)“ (Cabre 1999: 25). Подобно на всички други изследователи лингвистите неизбежно използват терминологията, свързана с „общия метаезик“ на езикознанието, като или приемат вече съществуваща терминология, която е конвенционализирана, или съставят собствен набор от термини. От изключителна важност и в двата случая е термините да се обясняват недвусмислено и да се използват последователно. Така например в своето изследване, чийто предмет е граматиката на наподобяващите апозиции единици в немския език, Волфганг Шиндлер (Schindler 1990) предлага собствена идиосинкратична терминология. Той мотивира своя избор като опит да дистанцира концепцията си от вече съществуващите термини и от теоретичните постановки на други учени и да позволи твърденията му да бъдат тествани спрямо тях (Stevens 1993: 182).

В науката обаче винаги е съществувал проблемът с терминологичната разнородност. Често срещано явление в научните изследвания (на един и същ автор или на различни учени), и поспециално в лингвистиката, е прекомерната и/или произволната употреба на различни термини, обозначаващи едно и също понятие, или използването на един и същ термин с различно значение. Тази 


\section{Годииник на ФХH, XXXII A}

неустановеност и променливост често прави метаезика на лингвистичната литература неясен и противоречив - проблем, който изследователите се налага да разрешават. В своята „Семантика“ Джон Лайънс обръща специално внимание на терминологичната неяснота, породена от употребата на множество термини и техни значения в литературата в областта на семантиката и семиотиката:

One of the biggest problems that I have had in writing this section of the book has been terminological. It is frequently the case in the literature of semantics and semiotics that the same terms are employed in quite different senses by different authors or that there are several alternatives for what is essentially the same phenomenon. All I can say is that I have been as careful as possible in selecting between alternative terms or alternative interpretations of the same terms and, within the limits of my own knowledge of the field, in drawing the reader's attention to certain terminological pitfalls.

(Един от най-големите проблеми, които срещнах при написването на този раздел от книгата, е терминологичният. Често се случва в литературата в областта на семантиката и семиотиката едни и същи термини да се използват в съвсем различен смисъл от различни автори или да съществуват няколко алтернативи за назоваване на едно и също явление. Всичко, което мога да кажа, е, че бях възможно най-внимателен при избора между алтернативни термини или алтернативни тълкувания на едни и същи термини и в границите на собствените си познания в областта, като насочих вниманието на читателя към определени терминологични клопки) (Lyons 1977: xi).

Един от ключовите проблеми в синтактичните изследвания, чийто обект е апозитивната конструкция, е свързан със значението, което се влага в основни латински или англоезични термини като: apposition или appositio (апозиция), appositive (апозитив), appositional (апозиционен) и производните от тях думи и словосъчетания с терминологично значение: апозитивност; апозитивен член; апозитивна функция; апозитивна връзка; апозитивно отночение; апозиционна двойка; апозитивно (слово)съчетание; словосъчетание от апозитивен тип; апозитивна фраза; апозитивна единица; апозитивна (апозиционна) структура (конструкция) и пр., които имат сравнително устойчива употреба не само в англоезичните изследвания по синтаксис.

Изборът на термини, които еднозначно и коректно отразяват различията между обозначените с тях понятия в съдържателен аспект, невинаги е достатъчно добре мотивиран и регламентиран от 
концептуална и/или от практическа гледна точка. Това е съществена предпоставка метаезиковата амбивалентност и комплицираност да повлияят на оптималното теоретично осмисляне на една от фреквентните, макар и все още недобре проучени, синтактични единици и на методологическата база на изследванията, чийто предмет са те. Терминологичните обозначения създават проблеми и при превода от език, в който определени термини имат установена, ясна и устойчива употреба, на език, в който няма дори приблизителни съответствия за тях. Буквалното възприемане на термините, чието значение често „,е разминава“ с първоначалния идеен замисъл и с авторовата интенция, и механичното им налагане причиняват още по-големи трудности и предпоставят нежелано изопачаване на мнения, хипотези, схващания или неволната им подмяна.

Граматическият термин apposition (англ. „apposition“, фр. „apposition“, нем. „Аpposition“, исп. „Аposicion“, чеш. „,aposice“) произхожда от латинската дума appositus, означаваща: „1. Situated near or opposite to, juxtaposed, adjacent“6 (разположен близо или срещу, съпоставен, прилежащ), която е производна от appono, apponere, apposui, „to place near or opposite (to), set alongside“ (поставям близо или срещу, поставям един до друг) (OLD 1968: 153). Произходът на термина apposition се свързва и с думата appositum, означаваща: „An adjective, epithet"“ (прилагателно, епитет) (OLD 1968: 153). Граматическият термин apposition се използва още през 1799 г. от френския лингвист АнтоанИсаак Силвестьр де Саси в книгата му „Principes de grammaire générale“. В нея той обособява определението като самостоятелна изреченска част, за чието назоваване се използва именно терминът apposition. Според автора в синтактичната категория определение се включват три субкатегории - същинско определение, приложение и подчинено определително изречение (Silvestre de Sacy 1822: 213-231).

Константин Орлов, който в своите изследвания, публикувани през втората половина на XX век, използва термина ,аппозитивность“ в значение на „прибавление, присоединение к господствующему слову слова или словосочетания с тождественным или близким значением“ (Orlov 1960: 29) и го тълкува като генетически, смислов (а не синтактичен) признак, проучва етимологията на думата appositio и на сродните ѝ думи. Според него латинската дума appositio означава „прибавяне, добавяне“; apposita означава „близко понятие“; appositum като граматически термин означава „прилагателно име“, а като реторически - „приложение, определение, епитет“; appositus в прякото 


\section{Годииник на ФХH, XXXII A}

си значение означава „намиращ се близо, стоящ до“, а в преносното си значение - „влизащ в съприкосновение, близък“ (Orlov 1960: 29).

Дори при беглия и без претенции за изчерпателност преглед на изследвания, в които базови понятия се обозначават по различен начин от различните автори (а понякога и от един и същ автор), може да се установи с колко разнородни, неочаквани, а понякога и с взаимноизключващи се значения се натоварват използваните термини. По-нататъшното изложение е опит да се представят, да се анализират и да се обобщят някои от грешките, непоследователностите и пропуските, регистрирани в несъмнено престижни и качествени научни трудове, чийто предмет е апозитивната конструкция.

Настоящото изследване е насочено отвъд анализа на един единствен език, но все пак вниманието на авторите се фокусира върху текстове на български, английски, немски и руски език. Разглежданите източници включват „,терминологични сборници“ или ,,ресурси“ (Wright and Budin 1997: 325-326), като речници и граматики, както и дисертации, академични издания и научни статии.

В началото на студията се дискутират въпроси, свързани с дефинирането на апозитивната конструкция. Следва опит за синтезиране и извеждане на набор от основни термини, които се използват с висока фреквентният като част от метаезика на изследванията, чийто обект е апозитивната конструкция, а именно: апозиция, апозитив, апозитивна конструкция, апозитивно отношение. В заключение се предлагат някои изводи, свързани с метаезика и терминологията, характерни за проучванията на апозитивната конструкция.

\section{Критически анализ на различията при дефинирането на апозитивната конструкция}

В научния дискурс е неприемливо и рисковано да се използват различни термини за обозначаването на едно и също понятие. Особено когато това се прави необосновано и невнимателно. В изследванията по български синтаксис терминът апозиция има спорадична и амбивалентна употреба. Красноречива илюстрация на статуквото е дефиницията, която Константин Попов предлага в едно от значимите проучвания по тази проблематика: „Апозицията (приложението) като синтактично понятие и като термин най-често означава атрибут в широк смисъл на думата, субстантивирана форма на атрибут или обособена част на изречението“ (Popov 1978: 207). 
B „A Comprehensive Grammar of the English Language“, една от най-популярните и авторитетни граматики на английския език, апозитивната конструкция е подробно разгледана. Рандолф Куърк и съавторите му дефинират т. нар. апозиция въз основа както на синтактични, така и на семантични критерии, приложени впрочем порано от Н. Софьр (Sopher 1971). В колективния синтетичен труд терминът apposition системно се използва в значение на „конструкция“, но и на „компонент на конструкция“, и на „отношение между компонентите“, а с термина appositive се обозначава или всеки от компонентите, или само този от тях, който е зависим (Quirk et al. 1985: 1300-1321). На практика, от една страна, за назоваване на няколко понятия се използва един и същ термин - apposition, а от друга страна, за назоваването на едно и също понятие (компонент на апозитивната конструкция) се употребяват и двата термина - apposition и appositive. Ако първото може да се оправдае с терминологичната полисемия, чието налагане е симптоматичен дискредитиращ фактор за терминологичните системи като цяло, второто затормозява вярната и своевременна интерпретация на конкретния текст.

В докторската си дисертация нидерландският лингвист Херман Херинга защитава идеята, че прототипната (истинската, същинската) апозитивна конструкция е само тази, в която зависимата част, именувана от него loose apposition, е отделена пунктуационно или интонационно, т. е. е обособена.

Коментирайки примери от типа: (4) a. Мy brother Peter is still at college и (4) b. My brother, Peter, is still at college, той използва термините restrictive example за (4a) и appositive variant за (4b), а компонентите, които Р. Куърк и съавторите му обозначават като appositives (двата компонента на апозитивната конструкция), Х. Херинга нарича anchor (котва, основа) и apposition (апозиция) (Heringa 2011: 3).

Джордж Кьрм, подобно на авторите на „А Comprehensive Grammar of the English Language“, употребява термина appositive за назоваване както само на зависимия, така и на всеки от двата компонента на апозитивната конструкция, а за да обозначи цялата конструкция, използва термините appositional group, appositional construction, close apposition или loose apposition (Curme 1931: 88-92; 1947: 129-131).

Други автори на значими научни трудове и справочни издания също използват един и същ термин (най-вече - apposition) за назоваване на различни понятия. Така например в придобилия световна известност „Merriam-Webster Dictionary“ (1997) терминът apposition ce дефинира 


\section{Годииник на ФХH, XXXII A}

едновременно като: „1 a: grammatical construction in which two usually adjacent nouns having the same referent stand in the same syntactical relation to the rest of a sentence (such as the poet and Burns in ,a biography of the poet Burns")“" (граматическа конструкция, в която две съседно разположени именни фрази имат еднаква референция и едно и също синтактично отношение спрямо дума в изречението извън конструкцията); и като: „b: the relation of one of such a pair of nouns or noun equivalents to the other" (отношение между именните фрази, които са компоненти на същата конструкция) (Merriam-Webster 1997: 97). Разбирането на авторите, отразено във втората част на дефиницията, драстично се отличава от масовата практика, възприета в англоезичната научна литература, отношението между компонентите на апозитивната конструкция да се обозначава с терминологичното съчетание in apposition (,,в отношение на апозиция“").

В „The Concise Oxford Dictionary of Linguistics“ професорьт от Оксфордския университет Питьр Матюс представя по-комплицирана позиция. Различията спрямо коментираните трудове са както по отношение на двойката термини, така и по отношение на тяхното съдържание. Той твърди, че с термина apposition трябва да се обозначава синтактичното отношение между намиращи се в юкстапозиция, т. е. съположени, елементи от един и същ вид. При това авторът разграничава апозицията от модификацията (modification) или от атрибуцията (attribution) по това, че не се наблюдава тенденция който и да е елемент (от двата) да квалифицира другия. С термина appositional според П. Матюс трябва да се обозначава: 1) „Standing in a relation of apposition (намиращ се в отношение на апозиция): е. g. the first president and George Washington are appositional noun phrases in the first president, George Washington"; 2) „Having a role like that of an element in apposition“" (функциониращ като елемент в апозиция) (Matthews 2003: 197-198). По отношение на първата част от дефиницията, отнасяща се до тълкуването на термина apposition, не може да има съществени несьгласия: мнозина други (най-вече англоезични) лингвисти използват този термин именно за да обозначат категорията синтактично отношение.

Втората част на дефиницията обаче предизвиква основателни резерви. От думите на П. Матюс е ясно, че, от една страна, с термина appositional noun phrases ce обозначават двата компонента на апозитивната конструкция. Това може да се приеме за приемлива, дори рутинна практика. От друга страна, терминът apposition се интерпретира амбивалентно - и като синтактично отношение, и като синтактична 
конструкция, срв.: „Having a role like that of an element in apposition“. Като се има предвид, че проф. П. Матюс е автор на престижната монография „Syntactic relations: A Critical survey“ (2007), е трудно да се приеме, че в неговата дефиниция е налице непоследователност. Вероятно обичайните изисквания относно обема на речниковите статии и принудителното редуциране на изказа е причина за допускането на двояко тьлкуване на термина apposition.

Дейвид Кристъл, сътрудник на Р. Куьрк в „Survey of English Usage“" и професор по лингвистика в университета Бангор в Уелс, отъждествява значението не на два, а на цели три термина, като неособено аргументирано „съчетава“ анализираните вече опозиции apposition - appositive и apposition - appositional. В многократно издавания си речник „А Dictionary of Linguistics and Phonetics“ авторът, дефинирайки базовия термин apposition, твърди, че става дума за традиционен термин, използван в някои модели на граматическо описание за обозначаване на последователност от компоненти (членове), които са конституенти на едно граматическо равнище и които имат еднаква или близка референция. В примера, даден от него: „John Smith, the butcher, came in“, има две именни фрази, които са с еднаква референция и изпълняват една и съща синтактична функция, което ще рече, че изпускането на единия или на другия компонент не води до нарушаване на приемливостта/правилността на изречението. Според автора: „They are therefore said to be in apposition or in an appositive or appositional relationship“ (Следователно се приема, че са в апозиция или в апозитивно или апозиционно отношение) (Crystal 2008: 31). Неслучайната алтернация в дефиницията недвусмислено показва, че използваните в нея три термина се интерпретират като абсолютни синоними, въпреки че с тях всъщност се обозначават различни граматически категории: 1) компонентите на апозитивната конструкция, взети поотделно; 2) последователността от тези компоненти; 3) синтактичното отношение между тях.

В някои съвременни разработки се демонстрира особен подход, при който метаезикът преднамерено и целенасочено се променя в рамките на един и същ текст. Така например В. Шиндлер декларира още в увода на своята дисертация, че възприема терминологията на Хорст Рабе, който тълкува термина apposition като наименование на цялата синтактична конструкция, а термина appositiv - като наименование на зависимия компонент в същата конструкция. Само че малко преди това В. Шиндлер пише, че апозицията (die Apposition) - или, както се нарича 


\section{Годииник на ФХН, XXXII $A$}

в края на труда му, допълването, прибавянето (der Zusatz) - се разглежда като синтактична релация между две единици. В същото време, полагайки усилия да оптимизира необичайния според него метаезик на X. Рабе, той смята, че за конструкцията, която се състои от основен елемент (Bezugselement - eine Basis), и елемент, отнасящ се към него (еine „Apposition“), трябва да се използва терминът апозитивна конструкичи (eine Appositionskonstruktion). Кавичките, с които авторът маркира термина Apposition, и начинът, по който коментира примерите си, вместо да спомогнат изложението да бъде прегледно и прецизно, затрудняват неговото възприемане и осмисляне. В една от приложените в началото на текста схеми (1.2.) терминът apposition се използва, за да се обозначи цялата апозитивна конструкция, а терминът appositiv се използва, за да се обозначи само зависимият компонент в нея, докато в следващата схема (1.3.) двата термина са използвани като синоними за обозначаване само на един от компонентите на апозитивната конструкция. В това отношение авторьт е категоричен:

In der vorliegenden Arbeit findet sich vor allem Raabes Sprachgebrauch, d.h. wenn ich sage, daß Y Appositiv zu/bzgl. X sei, dann ist das äquivalent mit der Aussage, Y sei Apposition zu/bzgl. X. (В настоящата работа се използва предимно езикът на Рабе, т.е. когато казвам, че Y е апозитив на $\mathrm{X}$, това е еквивалент на твърдението, че $\mathrm{Y}$ е апозиция на Х.) (Schindler 1990: 2).

Терминологичната комплицираност и частично компрометираната еднозначност пораждат известни съмнения относно основния подход, който е предпочел германският лингвист.

Сериозен размисъл предизвиква и становището на Олга Ахманова, която дефинира термина приложение (,аппозиция“) като „паратактическое соположение двух грамматически эквивалентных именных слов для выражения особого рода атрибутивной связи“ (Ahmanova 2004). Освен това тя разграничава: 1) „необособленное приложение“, напр.: „гражданин Иванов“; 2) „,обособленное приложение“, напр.: „Москва, столица СССР, один из красивейших городов мира“; 3) „предикативное приложение“ (predicative apposition), което се намира в атрибутивно-предикативно отношение спрямо определяемото съществително, т. е. обособено приложение, което се уподобява по смисъл с вторично сказуемо, напр.: „Иванов, прекрасный организатор и воспитатель молодежи, проявил себя и в этом деле“; „Мы проехали Кирсанов, важнейших пункт ссылки хлеба““(Ahmanova 2004). 
Ясно е, че в този случай става дума за метаезиков проблем, тъй като за обозначаването на еднакви от синтактична гледна точка конструкции (обособени части) са предпочетени различни термини.

Видно е, че проблеми от метаезиково естество възникват в рамките дори на един език. Когато обаче се наложи научните текстове да се превеждат, тези проблеми се задълбочават, а често и се мултиплицират. Така например Юлия Мишина се опитва да внесе яснота и еднозначност при транслирането на англоезични научни текстове, чийто предмет е апозитивната конструкция на руски език и констатира:

Обобщение теоретической базы осложняет терминологический метаязык, а именно использование русского термина „приложение“ наряду с его англоязычным аналогом „аппозитив“, которые употребляются либо как эквивалентные, либо предполагают наличие отличительных особенностей. В зарубежной литературе, говоря об ,аппозитиве““ основной акцент делается на аппозицию как процесс, в то время как языковые единицы, выступающие в составе аппозитивных конструкций, не получают должного внимания. В отечественном языкознании, наоборот, именно языковые единицы выступают на первый план (Mishina 2007: 46-47).

Въпреки по-големия обем на цитата прякото цитиране се използва, тъй като разсъжденията на авторката маркират отчетливо и недвусмислено проблемите, свързани с транслирането изобщо на научни текстове.

Дори да се приеме, при това - с голяма доза съмнение, че терминът приложение, използван в рускоезичната синтактична литература, е аналог на английския термин appositive, твърдението на Ю. Мишина: „... говоря об „аппозитиве“ основной акцент делается на аппозицию как процесс...“" разкрива двойственото ѝ отношение и неизбежните ѝ колебания (не само нейни, за съжаление), отразяващи трудностите при разграничаването на значенията, с които се употребяват термините appositive и apposition.

Критическият преглед на сериозни и авторитетни англоезични и немскоезични източници категорично показва, че актуалното противопоставяне по-скоро е между термините apposition, с който се обозначава цялата апозитивна конструкция или само един от нейните компоненти, и in apposition, с който се обозначава отношението между компонентите в тази конструкция. В рускоезичните синтактични изследвания термините аппозиция и аппозитив имат спорадична и периферна употреба, за разлика от термините аппозитивный, 


\section{Годииник на ФХH, XXXII A}

аппозитивная связь, аппозитивное отношение, които се използват твърде често. Най-вероятната причина за това е невъзможността от базовия термин приложение да се образуват производни съставни термини. Затова е необходимо да се прецизира мнението на Ю. Мишина, според която в руския синтаксис вниманието се фокусира върху структурните единици, а в английския синтаксис апозицията приоритетно се проучва като процес. И в англоезичната, и в немскоезичната, и в рускоезичната синтактична литература апозитивната конструкция все по-често е обект или предмет на задълбочени, целенасочени и тясно специализирани проучвания. Силно изразена тенденция, оформила се още през последните десетилетия на XX век, е, че в центъра на вниманието попадат не толкова въпросите, отнасящи се до синтактичното отношение между компонентите на апозитивната конструкция, колкото въпросите, свързани с морфологичните и семантичните характеристики на тези компоненти. Подчертаният интерес е закономерен и траен, тъй като отношението между компонентите е функция от семантичната и морфологичната им специфика.

Проблем, който вероятно може да бъде обект на отделно проучване, е начинът, по който се цитират мнения както на автори, пишещи на езика, използван от цитиращия, така и на автори, пишещи на чужд спрямо използвания от цитиращия език. Николай Корнилов в своята кандидатска дисертация цитира Александър Потебня, но начинът, по който го прави, създава невярното впечатление, че А. Потебня употребява термините аппозитивные члены и аппозиция в значение на „приложение“, срв.: „Аппозитивные члены (приложения), по мысли А. А. Потебни, имеют бо́льшую предикативность по сравнению с обычным определением-атрибутом. (...) Аппозиция (приложение) „имеет функцию, среднюю между собственным определением и определительным придаточным предложением с глагольным сказуемым“ (Kornilov 2012: 96-97). Всъщност в оригиналния текст на известния руско-украински езиковед системно се използва единствено терминът приложение и само веднъж (в бележка под линия) - неговото латинско съответствие appositio (Potebnya 1958: 110, 122).

По подобен начин, при това отново в дисертационен труд, с препратки към оригинални текстове си служи и вече цитираната Ю. Мишина. Така например тя отбелязва, че Р. Куърк и неговите съавтори разграничават необособено и обособено приложение, като, за да онагледи наблюденията си, некоректно приписва на Р. Куърк термините 
restrictive appositive (ограничительный аппозитив) $u$ nonrestrictive appositive (неограничительный аппозитив) . В същата работа погрешно се цитира и тезата на Реджиналд Клоуз, който в своята граматика не използва наименованията non-detached apposition и detached apposition (Mishina 2007: 38), a restrictive apposition и non-restrictive apposition (Close 1975: 22, 44). Вероятно резултат от невнимание или недоглеждане е и констатацията на авторката, че в руската лингвистика, наричана по традиция „отечествена“, Виктор Виноградов въвежда термините собственное приложение, с който се обозначава необособеното приложение, и придаточное/предикативное приложение, с които се обозначава предпоставеното или следпоставеното обособено приложение. Твърдението на авторката дори е подкрепено с цитат, който обаче не е от трудовете на академик В. Виноградов, а от излезлия доста по-рано „Синтаксис русского языка“ на неговия учител академик Алексей Шахматов (срв.: Shahmatov 2001: 280) (Mishina 2007: 38-39).

За разлика от изследванията на посочените автори в трудовете на други лингвисти се прави опит прецизно, последователно и добре обосновано да се прокара разделителна линия между термините, чрез които се обозначава едно и също понятие, и между понятията, които се обозначават чрез един и същ термин. Така например преди повече от век американската лингвистка Лилиан Кимбъл тълкува термините appositive и apposition по следния начин. С термина appositive се назовава име или именно словосъчетание, което служи като модификатор на съществително име или местоимение. В същата дефиниция обаче авторката уточнява: „When the base word of an appositive is a noun, it is called a noun in apposition“ (Когато основната дума на апозитива е съществително, то се нарича съществително в апозиция) (Kimball 2010: 87). Така тя ясно разграничава значенията на двата термина - с първия (an appositive) се назовава структурната единица, а с втория (in apposition) - синтактичното отношение. Освен това в своя базов труд Л. Кимбъл не използва термина appositive phrases, както се твърди в по-късни руски източници (например в дисертацията на Ю. Мишина (Mishina 2007: 37)).

Джордж Уайкоф и Хари Шоу също прецизно разграничават назованите с различни термини понятия. Те дефинират по следния начин термина appositive: „Appositive. A substantive added to another substantive to identify or explain it. The appositive signifies the same thing and is said to be in apposition." (Апозитив. Субстантив, който се прилага към друг субстантив, за да го идентифицира или за да го поясни. Апозитивът обозначава същото нещо и се приема, че е в апозиция.) (Wykoff, Shaw 


\title{
Годииник на ФХH, XXXII $A$
}

1952: 117). Така се избягва неоправданото и объркващо смесване на термини (и понятия), тъй като за назоваване на едно понятие (компонент на апозитивната конструкция) се използва единият термин - appositive, a за назоваване на синтактичното отношение между компонентите се използва другият термин - in apposition (т. е. „В апозиция“ или „в отношение на апозиция“).

Корелацията appositive - in apposition се представя по подобен начин и от Орин Серайт, според когото:

\begin{abstract}
A final definition for the appositive, then, is that it is ANY structure in ANY function which, in addition to modifying or renaming an antecedent, will also SUBSTITUTE for that antecedent. It may, of course, be restrictive or nonrestrictive, and it will always show a three-fold semantic, intonational and graphic correlation.

(Окончателната дефиниция на апозитива следователно е, че представлява каквато и да е структура с каквато и да е функция, която, освен че преименува или идентифицира антецедент, го и замества. Може, разбира се, да бъде рестриктивен и нерестриктивен и винаги ще бъде проява на триизмерна корелация - семантична, интонационна и графична.) (Seright 1966: 109).
\end{abstract}

Коректно и последователно са интерпретирани анализираните термини от професора от университета в Съсекс Робърт Траск в един от най-популярните англоезични речници на лингвистичните термини. В своята дефиниция известният лингвист последователно нарича зависимия компонент в апозитивната конструкция appositive, но в края заключава: „An appositive is said to be in apposition to the preceding NP“ (Trask 1996: 19). Следователно с термина appositive английският професор назовава един от компонентите на апозитивната конструкция, т. е. структурната единица, а с термина in apposition обозначава отношението между двата нейни компонента.

\section{Преглед на значенията, с които се използват базовите термини при описанието на апозитивната конструкция}

При анализа на множество чуждоезични синтактични изследвания може лесно да се установи, че основните термини в разглежданата проблематика - apposition, appositive, appositional construction, appositive relation - се използват с повече от едно значение. В някои от трудовете един и същ термин се използва, за да се назоват с него различни понятия; в други случаи един и същ автор - в резултат на по-несьществена или по- 
значима трансформация на възгледите си - променя и значението, с което употребява визираните термини.

В синтактичните трудове, посветени на разкриването на граматическия статус, характеристиките, типологията и употребата на апозитивната конструкция, с термина apposition (апозиция) се обозначава:

1) Съществително име, субстантивирана част или именно словосъчетание, което се отнася към друго съществително име, като го определя и дава друго наименование на обекта, вече означен с първото съществително. С това значение използват термина Люсиен Тениер (Tesnière 1969: 163-166), Борис Илиш (Ilyish 1971: 231), Герхард Хелбих и Йоахим Буша (Helbig, Buscha 1996: 606-609), Майк Ханей и Евълин Кайзър (Hannay, Keizer 2005: 163-164), Петер Галман (Grammatik 2009: 980-994), Петя Осенова (Osenova 2009: 162-163), Х. Херинга (Heringa 2011: 1) и др. Трябва да се отбележи, че именно това значение може да се приеме като най-популярно, като основно и в известен смисъл представително. При подобна употреба несъответствията в обема на термина са свързани с различното тълкуване на статуса на зависимия компонент в апозитивната конструкция.

Една част от авторите - Ото Йесперсен (Jespersen 1943: 93-95), О. Серайт (Seright 1966: 107-109), Р. Клоус (Close 1975: 43-44), Х. Рабе (Raabe 1979: 226, 329), Р. Куърк и съавторите му (Quirk et al. 1985: 13031306), Лариса Нехорошкова (Nehoroshkova 1989: 1-16), Чарлс Майер (Meyer 1992: 10-34), Хуан Карлос Акуня-Фариня (Acuña-Fariña 1996: 168), Джон Тейльр (Taylor 2002: 236), Новела Кобрина (Kobrina i dr. 2008) - твърдят, че зависимият компонент може да се изразява и чрез подчинено изречение, предикативно словосъчетание, инфинитивна конструкция.

Други допускат, че той може да се изразява дори с наречие, с прилагателно име или с глаголна форма. Сред тях са Хендрик Паутсма (Poutsma 1904: 183), Юлиус Хук и Ернст Матюс (Hook, Mathews 1956), А. Потебня (Potebnya 1958: 185-191), Алексей Руднев (Rudnev 1963: 154155), О. Серайт (Seright 1966: 108), Валентина Северянова (Sever'janova 1978), Р. Куърк и Сидни Грийнбаум (Quirk, Greenbaum 1991), Х. К. Акуня-Фариня (Acuña-Fariña 1996: 168), Катлийн О’Конър (O’Connor 2008), Н. Корнилов (Kornilov 2012: 119-120).

Някои изследователи - както руско- и англоезични, така и немскоезични - под apposition имат предвид апозитивна конструкция, в която зависимият компонент е единствено и само обособена част - A. 


\section{Годииник на ФХH, XXXII $A$}

Потебня (Potebnya 1958: 109-110), О. Йесперсен (Jespersen 1969), Хених Бринкман (Brinkmann 1971), Леонид Бархударов (Barhudarov 2008), Харьлд Вайнрих (Weinrich 1993: 361-364), Улрих Енгел (Engel 1996: 806811), Гизеле Цифонун (Grammatik 1997: 1648, 1661 f., 2036, 2038 ff., 2043), И. Пулеха (Puleha 1999: 20) и др. все още няма консенсус при разграничаването на същинската (прототипната) апозитивна конструкция от синтактичните структури, които обикновено се неглижират или се разглеждат като близки, сходни, периферни спрямо нея явления, напр.: слабата апозиция (weak apposition) и частичната апозиция (partial apposition) (Quirk et al. 1985: 1302-1303); свързаната апозиция (enge, gebundene Apposition) (Grammatik 1997: 2043), (Appositive Nebenkerne) (Grammatik 2009: 988-993); периферната апозиция (peripheral apposition) (Meyer 1992: 41) или групата на наподобяващите апозицията конструкции (appositionsverdächtige Konstruktion) (Schindler 1990: 1).

2) Синтактична конструкция, изградена от две съществителни имена (именни групи) с еднаква референция, в която едното съществително име (именна група) функционира като независим компонент, а другото - като зависим компонент. Тази интерпретация в най-изчистен вид се демонстрира от Р. Куърк, С. Грийнбаум, Дж. Лийч и Я. Свартвик (Quirk et al. 1985: 1300-1319), Е. Коктова (Koktová 1986: 6), Ч. Майер (Meyer 1992), Х. К. Акуня-Фариня (Acuña-Fariña 1999: 59-91; 2009: 453-481), Е. Кайзър (Kaizer 2007: 22-60), С. Муратова (Muratova 2018: 240-246).

3) Типът на отношението между двата компонента на апозитивната конструкция. Въплъщаването на подобно значение в термина apposition е типично най-вече за англоезичните изследвания, в които последователно се използва изразът in apposition в значение на „в апозиция“ или „в отношение на апозиция“. В зависимост от вижданията на лингвистите за характера на коментираното отношение може да се обособят няколко различни гледни точки.

3 a) Според О. Йесперсен (Jespersen 1969: 123), Ч. Хокет (Hockett 1955: 99-102), Р. Клоуз (Close 1975: 22), Д. Алертьн (Allerton 1979: 127129), К. Браун и Дж. Мильр (Brown, Miller 1980: 258), А. Щурм (Sturm 1986: 245), П. Лекант (Lekant 1977: 50; 2006: 298) и др. отношението между компонентите на апозитивната конструкция, първо, е синтактично, и второ, то трябва да се разглежда като разновидност на координацията, т. е. с термина apposition се обозначава отношение на координация между компонентите на апозитивната конструкция. Някои 
от тях, като В. Матезиус (Matezius 1967: 505), Ч. Фрайз (Fries 1952: 187), Н. Франсис (Francis 1958: 301), П. Робъртс (Roberts 1962: 219), Б. Богацки (Bogacki 1973: 19), М. Табоада (Taboada 1978: 315-340), отиват още подалече. Те използват този термин, за да обозначат юкстапозицията на кореферентни именни групи. Поддръжниците на тезата за съчинителния характер на отношението в апозитивната конструкция почти винаги декларират, че синтактичната тъждественост (еквивалентност) на нейните компоненти не води до семантичната им равнопоставеност и/или до изравняване на комуникативната им функция.

В съветското езикознание изявени адепти на подобно тълкуване относно статуса на граматическото отношение в апозитивната конструкция, без обаче да използват термина apposition, са А. Пешковски (Peshkovskiy 2001: 57-59, 141), А. Бескровни (Beskrovnyj 1940: 39-40), O. Ахманова (Ahmanova 2004). По-късно някои съветски и руски лингвисти „реанимират“ по своеобразен начин странно изглеждащата някога идея на А. Пешковски, като я допълват, прецизират и обогатяват, включително и терминологично. Екатерина Захаренко, която използва термина аппозитивная связь вместо аппозитивное отношение, смята, че апозитивната връзка е особен тип връзка, означаваща синтактично равенство между компонентите, които свързва, но непредполагаща задължително равенство между семантическите им статуси и комуникативните им роли (Zaharenko 1998: 12, 24). Според Н. Кобрина, една от авторките на Грамматика английского языка. Морфология. Синтаксис, която предпочита термина апозитивно отношение:

The sentences discussed above show the peculiarity of the appositive relation: although it resembles coordination syntactically (in that the headword and the apposition are constituents of the same level within the sentence), communicatively they are not of the same rank.

(Разгледаните по-горе изречения показват особеностите на апозитивното отношение: макар и синтактично да прилича на координацията, тъй като главната дума (the headword) и апозицията са съставни части (конституенти) на едно и също ниво в изречението, комуникативно те не са от един и същ ранг.) (Kobrina i dr. 2008).

3 б) Друга част от лингвистите, например X. Паутсма (Poutsma 1904: 183), Дж. Кьрм (Curme 1947: 129-131), Р. Хадлих (Hadlich 1973: 234) и др., твърдят, че отношението между компонентите на апозитивната конструкция е субординативно, затова с термина apposition се обозначава подчинителното отношение между главния и зависимия компонент. Тогава обаче с особена острота възникват въпросите кой от 


\section{Годииник на ФХH, XXXII A}

тях е независим и кой е зависим, както и въпросите, засягащи морфологичните и семантичните им характеристики. Някои от авторите приемат, че отношението в апозитивната конструкция е производно и/или се доближава до атрибутивното отношение, други, например Е. Дорон (Doron 1994: 53-65), Г. Цифонун и съавторите ѝ (Grammatik 1997: 2035; 2040), защитават тезата за неговия предикативен характер, а трети, като К. Потс (Potts 2005, цит. по: Heringa 2011: 8) и цитирания вече К. Орлов, смятат, че отношението не е синтактично, а семантично. Независимо от това обаче дали отношението се определя като атрибутивно, като предикативно, или дори като несинтактично - то се обозначава с един и същ термин - apposition (изключение прави К. Орлов, който използва термина аппозитивность).

В някои от рускоезичните изследвания, публикувани през втората половина на XX век, терминът apposition (приложение) се използва за назоваване не на подчинително отношение, а на подчинителна връзка. Татяна Малошная например разграничава синтактичната връзка аппозиция, която е разновидност на съгласуването, от синтактичната връзка именное примыкание (именно прилагане). За нея в словосъчетания от типа: журнал „Нева“, станция Москва, ледокол „Красин“, кинотеатр „Баррикады“, Всеволод Большое Гнездо (както между другото и в съчетания от типа: партия Ботвинник - Таль; встреча Де Голль Аденауэр; система человек - машина), е налице именное примыкание, затова те не са апозитивни. За разлика от тях словосъчетанието от собствено и фамилно име, напр.: Борис Кравчук (но и Кравчук Борис) е апозитивно (Moloshnaya 1975: 34, 44, 48).

Професорът от университета в Нюкасъл Ноел Бъртън-Робъртс също дефинира апозицията като изключително свободна и несъмнено нетипична синтактична връзка (а не като синтактично отношение), в която вторият елемент се добавя като вмятане към първия, а понякога функционира като металингвистично тълкуване или коментар спрямо него (Burton-Roberts 1994: 184).

3 в) Една голяма част от лингвистите - както в миналото, така и днес - настойчиво и ефективно защитават тезата за уникалния характер на отношението между компонентите на апозитивната конструкция. Това на практика означава, че то се осмисля като трети тип граматическо отношение, различен и от координацията, и от субординацията. За Н. Софър например отношението между елементите, намиращи се в апозиция, не е координация, защото те са кореферентни, а не е субординация, защото те са функционално еквивалентни (Sopher 1971: 
401-412). Въпреки това в трактовката на израелския лингвист е налице известно колебание при идентифицирането на това отношение, което ясно проличава от използваните от него термини head group и appositional group. Това означава, че все пак, макар и имплицитно, се прокрадва идеята за наличието на подчинително отношение. Други автори са последователни и категорични. Е. Делорм и Р. Дохърти (Delorme, Dougherty 1972: 2-29), Й. Битеа (Bitea 1977), Е. Коктова (Koktová 1986: 134), Дж. Тейльр (Taylor 2002: 235) използват термина apposition именно за да назоват този дискусионен, несъвпадащ нито с координацията, нито със субординацията, тип отношение.

В. Шиндлер (Schindler 1990) изгражда своята дисертационна теза, като целенасочено използва ключови идеи на Вернер Хакел: „Bei den appositionellen Konstruktionen haben wir (...) von einem Verhältnis wechselseitiger Bedingtheit auszugehen“. (При апозитивни конструкции трябва да изхождаме от едно отношение на променлива условност.) (Hackel 1968: 88, цит. по: Schindler 1990: 48), и на Петер Айзенберг: „Die Formulierung $>\mathrm{X}$ ist Apposition $\mathrm{zu} \mathrm{Y}<$ besagt, daß $\mathrm{X}$ die Apposition und $\mathrm{Y}$ der Kern ist, auf den $X$ bezogen ist. Sind Kern und Apposition nicht zu unterscheiden, dann ist diese Redeweise hinfällig und muß ersetzt werden durch $>\mathrm{X}$ ist Apposition zu Y und Y ist Apposition zu X (Dieser Fall tritt häufig ein (...)“ (Ако ядро и апозиция не могат да се различат, тогава този начин на изразяване отпада и трябва да се замести с X е апозиция на Y и Y е апозиция на X (Този случай се среща често) (Eisenberg 1986: 243).

Германският учен анализира съществуването на апозицията през призмата на т. нар. синтагматика на люлката (Schaukelsyntagmatik), определяно също като „объркване на конструкцията““ (die „Kopflosigkeit““ der Konstruktion), респ. ,„удвояване на главите“" (die „Doppelköpfigkeit" безусловно възприема вижданията за характера на връзката в апозитивната конструкция на К. Леман (Lehmann 1983: 339-341) и на X. Рабе (Raabe 1979: 226). Така той стига до заключението, че има три типа синтактични релации: субординация - зависимост между членовете на релацията; координация - липса на зависимост между членовете на релацията; и адординация - релация между независими членове, които обаче не са равнопоставени. Според В. Шиндлер граматическото отношение между компонентите на апозитивната конструкция е от третия тип - адординативно (Schindler 1990: 47-50). Терминът, с който той назовава това отношение обаче, е именно apposition.

Колкото оригинална, толкова и амбивалентна е гледната точка и на Ч. Майер. В началните страници на монографията си той анализира 


\section{Годииник на ФХH, XXXII $A$}

апозицията като граматическо отношение (apposition as a grammatical relation), като го поставя на една плоскост с други според него граматически релации - координационно отношение (coordination), комплементарно отношение (complementation), модификация (modification) и паратактично отношение (parataxis) (Meyer 1992: 5-6). По-нататьк в изложението си Ч. Майер развива тезата, че апозицията (apposition) не може да бъде описана като конвенционално граматическо отношение (като координацията и модификацията). Според него тя би могла да се интерпретира като недиференцирано отношение (an undifferentiated relation), както предлага П. Матюс (Matthews 1981: 224), тоест като отношение на различни градирани (gradable) нива. Това означава, че не е възможно да се предложи само една конституентна структура за всички видове апозиция. Ако вместо това апозицията се разглежда като недиференцирано отношение или като отношение на различни (gradable) нива, е възможно да се разграничат конструкции, които са най-апозитивни (central appositions), и конструкции, които в различна степен са по-малко апозитивни (peripheral appositions). Следователно легитимирането на конкретна конституентна структура на апозицията зависи от степента, в която единиците ѝ са структурно зависими една от друга (Meyer 1992: 41).

Сходни идеи, но описани с други термини, характерни за рускоезичните източници, се разработват и се лансират в съветското и руското езикознание от А. Мухин (Muhin 1974: 240-247), Г. Уханов (Uhanov 1974: 336-342), В. Северянова (Severyyanova 1978), Т. Кочеткова (Kochetkova 2005), Е. Стародумова (Starodumova 2005: 22-26), А. Прияткина (Priyatkina 2007: 22). Трябва да се отбележи, че уязвимите твърдения, сериозните противоречия и взаимно изключващите се тези в тях категорично преобладават спрямо консенсусните анализи и рационалните решения .

В руската лингвистика в най-завършен вид възгледът за статуса на отношението между компонентите на апозитивната конструкция, според който то се отграничава както от координацията, така и от субординацията, е представен от А. Ломов. Сходствата между неговия възглед и идеята на Н. Софьр са очевидни, но трябва да се признае, че А. Ломов я прецизира и до известна степен я усъвършенства. В своя „Словарь-справочник по синтаксису современного русского языка“ той пише, че спецификата на референтната отнесеност е основната причина за тази трудно поддаваща се на анализ и концептуализиране диференциация. Според него връзката (той говори за връзка, а не за 
отношение!) не е съчинителна, защото съчинително се свързват само думи, чрез които се назовават различни референти. Тя не е и подчинителна, защото тъждеството на компонентите в апозитивните словосъчетания, които формално не зависят един от друг, е обусловено от отнесеността на двете номинации към един и същ референт (Lomov 2007: 18). Показателен обаче е фактът, че особената синтактична връзка, която анализира А. Ломов, така и не получава не само наименование, но и достатъчно приемлива обосновка.

3 г) При прегледа на синтактичните проучвания, свързани с референциално идентичните компоненти на бисубстантивните словосъчетания, се установява и още едно значение, с което се използва терминът apposition. C него се назовава граматическо отношение, което има синкретичен характер, т. е. в него се съвместяват признаци както на координацията, така и на субординацията. Преди около стотина години германският лингвист Йон Рис (1928) представя тезата си, чиято същност e, че апозитивните съчетания (Anfügegruppen, като част от Halbenge Gruppen), в които са налице както признаци на паратаксиса, така и признаци на хипотаксиса, са своеобразна преходна зона между съчинителните словесни групи (Lockere Gruppen) и подчинителните словесни групи (Enge Gruppen) (Ries 1928). В по-ново време Н. БъртънРобъртс предлага добре аргументираната си идея, че апозицията и координацията са деривати на една и съща дълбинна структура (BurtonRoberts 1975: 406), която има не един и двама поддръжници. Разбира се, дори при бегла съпоставка на концепциите на Р. Куърк и съавторите му (Quirk et al. 1985: 1301), на П. Матюс (Matthews 1981: 220), на Ч. Майер (Meyer 1992), а и на основно променената концепция на Н. БъртънРобъртс (1994), могат да се установят различия и несъответствия. Като цяло обаче е безспорно, че терминът apposition започва да се интерпретира по нов начин.

В бившия СССР изследователските търсения в тази посока отдавна са във фокуса на вниманието. В популярните в съветската и в руската лингвистика концепции не се използва терминът apposition, за да ce означи отношението между компонентите на апозитивната конструкция, но идеята за съчетаване на признаци, типични и за координацията, и за субординацията, за откриване на идеалната „пресечна точка“ между съчинението и подчинението е несъмнено актуална. Тя - по-имплицитно и плахо или по-ярко и категорично - се реализира в трудовете на Г. Циганенко (Cyganenko 1954: 1-16), М. Шатух (Shatuh 1954: 13), Е. Кротевич (Krotevich 1956: 9), В. Ицкович (Ickovich 


\section{Годииник на ФХH, XXXII $A$}

1963: 3-10), Е. Атаян (Atajan 1968), А. Михневич (Mihnevich 1968: 106112), А. Каминина (Каmynina 1970: 25), Р. Вацеба (Vaceba 1973: 159-160), Н. Корнилов (Kornilov 2012: 70, 82, 84-85, 140) и др.

4) Отделно внимание изисква все по-привлекателната идея, която се налага през 70-те и 80-те години на XX век, за неграматическия (несинтактичния) характер на отношението между компонентите на апозитивната конструкция. Практическото изключване на координацията и на субординацията като възможни варианти при неговото дефиниране обуславя тьрсенето на други гледни точки. Този оправдан интерес рефлектира в създаването на иновативни, екстраординарни, дори крайни, мнения. Те се обединяват около тезата, че щом отношението между компонентите на апозитивната конструкция не е нито съчинително, нито подчинително, то не е изобщо синтагматично (синтактично). В най-прецизиран вид тази идея се налага от П. Питьрсън (Peterson 1999: 229-250). Нейни привьрженици са и ЖанМари Зам (Zemb 1968: 296), Н. Бъртьн-Робъртс (Burton-Roberts 1975, 1994), Д. Лангре (Longrée 1987: 199), според които анализираното отношение не е предмет на проучване от граматиката, и в частност - от синтаксиса, т. е. в техните изследвания терминът apposition се използва, за да обозначи този уникален тип несинтактично отношение.

М. Ханей и Е. Кайзър, които използват същия термин, твърдят, че апозицията е частен случай на холофрастично изразяване, т. е. независима дискурсна единица със своя собствена пропозиция (Hannay, Keizer 2005: 163-164), което означава, че тя се разглежда като чисто прагматичен феномен.

5) В лингвистиката съществуват и екстремални, неособено популярни гледни точки относно значението, което се влага в термина apposition. Според Дж. Синклер например този термин е нефункционален, тъй като с него се назовават твърде много понятия, явления и категории в граматиката (Sinclair 1972: 252).

$\mathrm{C}$ термина appositive (апозитив) се обозначава:

1) Всеки от компонентите на апозитивната конструкция, както например го използват Р. Куърк и съавторите му (Quirk et al. 1985: 1302).

2) Зависимият компонент в апозитивната конструкция, който се противопоставя на независимия, наричан главна дума, head noun (unit), anchor. Подобни употреби се регистрират в проучванията на Дж. Кьрм (Curme 1947: 129-131), У. Уот (Wat 1964: 463), О. Серайт (Seright 1966: 107-109), Х. Вайнрих (Weinrich 1993: 361-364), Е. Захаренко (Zaharenko 1998: 16-21), Х. К. Акуня-Фариня (Acuña-Fariña 1999: 59-91), Х. Бусман 
(Bussmann: 2006: 78), Е. Катанова (Katanova 2007: 68-74), С. Муратова (Muratova 2018: 240-246).

3) Цялата апозитивна конструкция, както например се използва терминът в краткото, но твърде често цитирано изследване на Ч. Хокет (Hockett 1955: 99-102).

4) Частен случай на разширяване на изречението, а именно редупликация, при който удвоените компоненти имат един и същ референт, например у Д. Бразил (Brazil 1995: 121).

C термина appositional construction (апозитивна конструкция) се обозначава:

1) Синтактична единица, съдържаща независим (anchor) и зависим (apposition) компонент. С това значение терминът последователно и системно се използва в докторската дисертация на X. Херинга (Heringa 2011).

2) Непредикативни структури, в които зависимият елемент се изразява чрез дума или словосъчетание, и предикативни структури, в които зависимият елемент се изразява чрез подчинено изречение, например у Ю. Мишина (Mishina 2007: 17).

$\mathrm{C}$ термина appositive relation (апозитивно отношение) се обозначава:

1) Тип субординативно отношение, при което чрез втория компонент не само се назовава повторно референтьт, вече назован от първия компонент, но и се определя, уточнява, пояснява, характеризира първият компонент, например у А. Шахматов (Shahmatov 2001: 279) и Е. Кротевич (Krotevich 1956: 9).

2) Чисто прагматически, семантичен или интонационен феномен, който се изключва изобщо от синтаксиса. В изследванията на лингвистите, които използват термина в това значение - Е. Коткова (Koktová 1986: 1-34), Н. Бъртън-Робъртс (Burton-Roberts 1994), П. Питърсън (Peterson 1999: 247), Х. Херинга (Heringa 2011: 7) - е налице неоправдано смесване и своеобразно преплитане (доста често имплицитно) на употребата на два термина - apposition и appositive relation - с които всъщност се обозначава едно и също понятие, а именно апозитивно отношение.

3) Синтактично отношение, различаващо се както от субординацията, така и от координацията, например в изследването на С. Муратова (Muratova 2018: 240-246).

4) Особен вид синтактична връзка, с чиято помощ се обозначава синтактичното равенство (тъждество) между компонентите в 


\section{Годииник на ФХH, XXXII A}

апозитивната конструкция. То обаче не предполага равенство на семантично равнище или по отношение на функцията им, например в дисертационния труд на Е. Захаренко (Zaharenko 1998: 16-21).

\section{Заключение}

Закономерно налагащите се изводи след прегледа на начините, по които се използват базови термини в синтактичните изследвания, чийто предмет са граматическият статус, типологията и употребата на апозитивната конструкция, са:

1) В съществена част от анализираните научни трудове термините apposition, appositive, appositional, appositional construction, appositive relation и производните им думи и словосъчетания с терминологична употреба се използват коректно, добре обосновано и последователно.

2) В друга част от изследванията върху тази проблематика всеки от посочените термини се използва, за да се обозначава с него повече от едно понятие или за да се обозначава едно и също понятие с няколко термина. И в двата случая става дума за неточна, неприемлива, нежелателна употреба.

3) Вероятната причина за (не)съзнателното смесване, преплитане, дублиране и подмяна на термините (и значенията им) е самата природа на апозитивната конструкция, която трудно се поддава на ефективна „дисекция“ поради амбивалентния семантико-граматически потенциал и на двата ѝ компонента. Обстоятелството, че чрез едно съществително име или именна група се идентифицира и/или се характеризира друго име или именна група (без граматически изразена връзка между тях), се превръща в обективна и сериозна предпоставка за несполуките при анализа на апозитивната конструкция.

4) Неправилното смесване на термини и на терминологични значения влияе пряко и силно върху коректното представяне, възприемане и осмисляне на теоретичните постановки и на авторовата интенция. Т. нар. апозиция и без друго е в достатъчна степен енигматичен, странен и труден за интерпретиране граматически феномен. Ако и метаезиковият инструментариум, вместо да оптимизира продукцията и рецепцията на научния текст, ги затормозява, опитите да бъде правилно интерпретирана идеята, няма как да се увенчаят с успех.

5) Всеки изследовател има правото да подбира методите, подходите, механизмите и средствата, чрез които реализира авторовия си замисъл. Част от този избор, и то съществена част, е предпочетената 
терминологична система, както и начинът, по който тя се използва. В интерес на автора, а и в интерес на аудиторията, е изложението да е ясно, непротиворечиво, достатъчно добре аргументирано. Възможно е един лингвист да си служи с термина apposition, за да обозначи цялата апозитивна конструкция, а друг да го използва, за да обозначи отношението между компонентите ѝ (разбира се, при наличие на ясни, навременни и обосновани уточнения). Възможно е и в рускоезичната литература например терминът apposition да ce превежда като „приложение“. Неприемливо е обаче, когато един и същ автор използва различни терминологични съчетания, за да назове едно и също понятие (например използването на термините apposition и appositive в значение на ,зависим компонент на апозитивната конструкция“"). Неприемливо е и когато авторът назовава различни понятия с един и същ термин в един и същ текст (например обозначаването с термина apposition както на цялата апозитивна конструкция, така и на зависимия ѝ компонент).

6) Независимо от иманентната си условност и характера си на метаезикови текстови единици, термините са еднозначни, устойчиви, точни и системни обозначения, с чиято същност не бива да се злоупотребява. Безспорен факт е, че в последно време полисемията в терминологичните системи все по-осезателно доминира, а еднозначността на термините по-скоро се интерпретира като тенденция, a не като задължителна характеристика. Въпреки това при анализа и осмислянето на амбивалентен и комплициран семантико-граматически феномен като апозитивната конструкция трябва в максимална степен да се планира, да се прецизира и да се мотивира употребата на терминологичните единици.

Това важи за изследователите, които използват концептуалния апарат, принадлежащ на един език, но още повече е в сила за лингвистите или за преводачите, които трансферират знания в понятийната система на друга езикова култура. Идиосинкратичният характер на всяка езикова традиция често е източник на конфликти между концептуалните области на изходния и целевия език, съответно - между техните терминологични системи. Задълбоченото проучване на понятийните и терминологичните основи на изследванията, чийто предмет е апозитивната конструкция, може да помогне за разрешаването на металингвистичните проблеми и на теоретичните неясноти. Това, разбира се, трябва да става, като се отчита спецификата на всяка езикова традиция - независимо дали става въпрос за създаване на научен текст или за неговия превод на друг език. Чрез настоящото изследване се доказва необходимостта от прозрачност 


\section{Годишник на ФХН, XXXII $A$}

и последователност при използването на „общия метаезик“ посредством критическо проучване на терминологични употреби в лингвистичните изследвания на различни езици. Представените в студията наблюдения, констатации и изводи могат да послужат като отправна точка за разработването на солидна основа за изследователски проекти, чиято цел е описанието и анализирането както на идиосинкратичните, така и на универсалните характеристики на апозитивната конструкция като граматическа единица.

ИЗПОЛЗВАНА ЛИТЕРАТУРА:

Acuña-Fariña 1996: Acuña-Fariña, J. C. The puzzle of apposition. On so-called appositive structures in English. Universidade de Santiago de Compostela: Servicio de Publicacións e Intercambio Científico.

Acuña-Fariña 1999: Acuña-Fariña, J. C. On apposition. // English Language and Linguistics 3.1: 59-81. Cambridge University Press.

Acuña-Fariña 2009: Acuña-Fariña, J. C. Aspects of the grammar of close apposition and the structure of the noun phrase. // English Language and Linguistics 13.3: 453-481. Cambridge University Press.

Ahmanova 2004: Ahmanova, O. S. Slovary lingvisticheskih terminov, 2-e izd., ster. Moskva: URSS: Editorial URSS [Ахманова, О. С. Словарь лингвистических терминов, 2-е изд., стер. Москва: УРСС: Едиториал УPCC] < https://classes.ru/grammar/174.Akhmanova/source/worddocuments /_16.htm (status 6.08.2021) >.

Allerton 1979: Allerton, D. J. Essentials of Grammatical Theory. London: Routledge. Andreychin 1942: Andreychin, L. Osnovna balgarska gramatika. Sofia: „Hemus A.D.“ [Андрейчин, Л. Основна българска граматика. София: „Хемус А.Д."].

Atajan 1968: Atajan, Je. R. Predmet i osnovnye ponyatiya strukturalynogo sintaksisa. Erevan: Izd-vo MITK [Атаян, Э. Р. Предмет и основные понятия структурального синтаксиса. Ереван: Изд-во МИТК].

Barhudarov 2008: Barhudarov, L. S. Struktura prostogo predlozheniya sovremennogo angliyskogo yazyka. Moskva: LKI [Бархударов, Л. С. Структура простого предложения современного английского языка. Москва: ЛКИ] <https://classes.ru/grammar/116.Barhudarov/html/ unnamed_64.html (status 6.08.2021)>.

BJS 1998: Yazykoznanie. Bolyshoy jenciklopedicheskiy slovary. 2-e izd. Moskva: Bolyshaya Rossiyskaya jenciklopediya [Языкознание. Большой энциклопедический словарь. 2-е изд. Москва: Большая Российская энциклопедия].

Beskrovnyy 1940: Beskrovnyy, A. E. Konspekt lekciy po sintaksisu russkogo yazyka. Vyp. 1. Krasnodar: Krasnodarskaya tipografiya [Бескровный, A. Е. 
Конспект лекций по синтаксису русского языка. Вып. 1. Краснодар: Краснодарская типография].

Bitea 1977: Bitea, I. N. An Attempt at defining apposition in modern English. // Revue Roumaine de Linguistique: pp. 453-477.

Bogacki 1973: Bogacki, B. K. Types de constructions appositives en français. Wrocław: Polska Akademia Nauk. Komitet Językoznawstwa 73.

Brazil 1995: Brazil, D. A Grammar of Speech. London: Oxford University Press.

Brinkmann 1971: Brinkmann, H. Die deutsche Sprache: Gestalt und Leistung. Düsseldorf: Schwann.

Brown, Miller 1982: Brown, E. K., J. E. Miller. Syntax: Generative Grammar. London: Hutchinson.

Burton-Roberts 1975: Burton-Roberts, N. Nominal apposition. // Foundations of Language 13: 391-419.

Burton-Roberts 1994: Burton-Roberts, N. Apposition. - In: The Encyclopedia of Language and Linguistics. R. E. Asher \& J. M. Y. Simpson (eds.), vol. 1, Oxford: Pergamon Press, pp. 184-187.

Bussmann 2006: Bussmann, H. Routledge Dictionary of Language and Linguistics. Translated and edited by Gregory P. Trauth and Kerstin Kazzazi. First published 1996 by Routledge 11 New Fetter Lane, London EC4P 4EE. This edition published in the Taylor \& Francis e-Library.

Cabre 1999: Cabre, M. T. C. Terminology: Theory, Methods and Applications. Universitat Pompeu Fabra. Sager J. C. (ed.), DeCesaris (trans.). Amsterdam / Philadelphia: John Benjamins.

Close 1975: Close, A. R. A Reference Grammar for the Students of English. London: Longman.

Crystal 2008: Crystal, D. A Dictionary of Linguistics and Phonetics 6th Edition. Blackwell Publishing Ltd.

Curme 1931: Curme, G. O. A Grammar of the English Language. Vol. 3. Syntax. North-Western University, USA <https://arrow.latrobe.edu.au /store/3/4/5/9/1/public/B12849467.pdf (status 6.08.2021)>.

Curme 1947: Curme, G. O. English grammar. New York: Barnes \& Noble. $<$ https://babel.hathitrust.org/cgi/pt?id=mdp.39015042004724\&view=1up\&s $\underline{\mathrm{eq}}=106$ (status 6.08.2021) $>$.

Cyganenko 1954: Cyganenko, G. P. Prilozhenie v sovremennom russkom yazyke: Avtoref. dis. ... kand. filol. nauk. Harykov [Цыганенко, Г. П. Приложение в современном русском языке: Автореф. дис. ... канд. филол. наук. Харьков].

Delorme, Dougherty 1972: Delorme, E., R. C., Dougherty. Appositive NP constructions: we, the men; we men; I, a man; etc. // Foundations of Language 8 (1): 2-29.

Doron 1994: Doron, E. The discourse function of appositives. - In: R. Buchalla \& A. Mitwoch (eds.), Proceedings of the ninth annual conference of the Israel 


\section{Годииник на ФХH, XXXII A}

Association for Theoretical Linguistics and of the workshop on discourse. Jerusalem: Hebrew University, pp. 53-65.

Eisenberg 1986: Eisenberg, P. Grundriss der deutschen Grammatik. Stuttgart: Metzler.

Engel 1996: Engel, U. Deutsche Grammatik. 3 korrigierte Auflage. Heidelberg: Groos.

Francis 1958: Francis, W. N. The Structure of American English. New York: Ronald.

Fries 1952: Fries, Ch. C. The structure of English: An introduction to the construction of English sentences. New York: Harcourt, Brace \& World.

Getsov 2019a: Getsov, A. Kontseptsii za gramaticheskoto otnoshenie v apozitivnite konstruktsii (2. chast). // Proglas, kn. 1, 2019, (XXVIII), s. 103-110. [Гецов,

A. Концепции за граматическото отношение в апозитивните конструкции (2. част). // Проглас, кн. 1, 2019, (XXVIII), с. 103-110] <http://journals.uni-vt.bg/proglas/bul/vol28/iss1/12 (status 6.08.2021)>.

Getsov 2019b: Getsov, A. Neobosobena apozitsiya vs. obosobena apozitsiya. // Godishnik na Fakulteta po humanitarni nauki, tom XXX A. Shumen: UI „Episkop Konstantin Preslavski“, s. 217-255. [Гецов, А. Необособена апозиция vs. обособена апозиция. // Годишник на Факултета по хуманитарни науки, том XXX А. Шумен: УИ „Епископ Константин Преславски“, с. 217-255] <http://shu.bg/sites/default/files/ izdaniq/fhn/godishnici/Godishnik2019.pdf (status 6.08.2021)>.

Grammatik 1997: Grammatik der deutschen Sprache. Hrsg. von G. Zifonun, L. Hoffmann, B. Strecker. Bd. 3, Berlin; New York: de Gruyter.

Grammatik 2009: Die Grammatik: Unentbehrlich für richtiges Deutsch: Band 4. 8. Aufgabe: Dudenferlag. Manheim - Wien - Zürich.

Griesbach 1972: Griesbach, H., Schulz, D. Grammatik der deutschen Sprache. Munich: Max Hueber Verlag.

Gvozdev 1968: Gvozdev, A. N. Sovremennyy russkiy literaturnyy yazyk. Izd. 3-e. Moskva: Prosveshhenie [Гвоздев, А. Н. Современный русский литературный язык. Изд. 3-е. Москва: Просвещение].

Hackel 1968: Hackel, W. Personen Eigennamen als kasus neutrale Apposition. Sprachpflege 6. - Leipzig.

Hadlich 1973: Hadlich, R. L. Gramática transformativa del español. Madrid: Gredos.

Hannay, Keizer 2005: Hannay, M., Keizer, E. A Discourse Treatment of English Non-Restrictive Nominal Appositions in Functional Discourse Grammar. In: Studies in Functional Discourse Grammar. J. L. Mackenzie \& M. de los Ángeles Gómez-González (eds.), Bern: Peter Lang, pp. 159-194.

Helbig, Buscha 1996: Helbig, G., Buscha, J. Deutsche Grammatik. Ein Handbuch für den Ausländerunterricht. 17. Auflage. Langenscheidt: Verlag Enzyklopädie: Leipzig; Berlin; München; Wien; Zürich; New York.

Heringa 2011: Heringa, H. Appositional Constructions. University of Groningen. Published by LOT Trans 103512 JK Utrecht, The Netherlands. 
<https://www.rug.nl/research/portal/files/2449766/Thesis_appositional_cons tructi_1.pdf (status 5.08.2021)>.

Hockett 1955: Hockett, Ch. F. Attribution and Apposition. // American Speech 30: 99-102.

Hook, Mathews 1956: Hook, J. N., E. G. Mathews. Modern American Grammar and Usage. New York: The Ronald Press Co.

Ickovich 1963: Ickovich, V. A. O tipah svyazi slov v predlozhenii. // Russkiy yazyk v nacionalynoy shkole, 1963, № 1, s. 3-10 [Ицкович, В. А. О типах связи слов в предложении. // Русский язык в национальной школе, 1963, № 1, c. 3-10].

Iliev 1988: Iliev, At. Sintaksis na balgarskiya ezik. Plovdiv: „Hr. G. Danov“ [Илиев, Ат. Синтаксис на българския език. Пловдив: „Хр. Г. Данов“"].

Ilyish 1971: Ilyish, B. A. Stroy sovremennogo angliyskogo yazyka: uchebnik po kursu teoreticheskoy grammatiki. Leningrad: Prosveshhenie [Ильиш, Б. А. Строй современного английского языка: учебник по курсу теоретической грамматики. Ленинград: Просвещение].

Jespersen 1943: Jespersen, O. Essentials of English Grammar. London: George Allen \& Unwin Ltd. <https://ia801606.us.archive.org/21/items/in.ernet.dli.2015. 16842/2015.16842.Essentials-Of-English-Grammar.pdf (status 6.08.2021)>.

Jespersen 1969: Jespersen, O. Analytic Syntax. New York: Holt, Rinehart and Winston.

Jung 1973: Jung, W. Grammatik der deutschen Sprache. Leipzig: Verlag VEB. Bibliographisches Institut. Leipzig.

Kamynina 1970: Kamynina, A. A. O podchinitelynyh svyazyah slov v prostom predlozhenii: Uchebnoe posobie. Moskva: Izd-vo MGU [Камынина, A. A. O подчинительных связях слов в простом предложении: Учебное пособие. Москва: Изд-во МГУ].

Katanova 2007: Katanova, E. N. Appozitivnaya konstrukciya kak sredstvo vyrazheniya samoidentificiruyushhego suzhdeniya. // Vestnik Voronezhskogo gosudarstvennogo universiteta. Seriya: Lingvistika i mezhkulyturnaya kommunikaciya, 2007, № 2, ch. 1, s. 68-74 [Катанова, Е. H. Аппозитивная конструкция как средство выражения самоидентифицирующего суждения. // Вестник Воронежского государственного университета. Серия: Лингвистика и межкультурная коммуникация, 2007, № 2, ч. 1, с. 68-74].

Keizer 2007: Keizer, E. The English Noun Phrase. The Nature of Linguistic Categorization (Studies in English Language). Published in the United States of America by Cambridge University Press, New York.

Kimball 2010: Kimball, L. G. English Grammar. By Lillian Gertrude Kimball. Forgotten Books AG. <https://archive.org/details/englishgrammar00 kimbgoog/page/n8 (status 6.08.2021)>. 


\section{Годииник на ФХH, XXXII $A$}

Kobrina i dr. 2008: Kobrina, A. N., E. A. Korneeva, M. I. Ossovskaya, K. A. Guzeeva. Grammatika angliyskogo yazyka. Morfologiya. Sintaksis. Moskva: Izdatelystvo „Soyuz“ [Кобрина, А. Н., Е. А. Корнеева, М. И. Оссовская, К. А. Гузеева. Грамматика английского языка. Морфология. Синтаксис. Москва: Издательство „Союз“] <http://robotlibrary.com/book/38grammatika-anglijskogo-yazyka-morfologiya-sintaksis/127-theapposition.html (status 6.08.2021)>.

Kochetkova 2005: Kochetkova, T. I. Slovoslozhenie kak sredstvo nominacii i predikacii $\mathrm{v}$ sovremennom russkom yazyke. Avtoreferat dissertacii na soiskanie uchenoy stepeni doktora filologicheskih nauk. Moskva [Кочеткова, Т. И. Словосложение как средство номинации и предикации в современном русском языке. Автореферат диссертации на соискание ученой степени доктора филологических наук. Москва] <http://cheloveknauka.com/slovoslozhenie-kak-sredstvo-nominatsii-ipredikatsii-v-sovremennom-russkom-yazyke (status 6.08.2021)>.

Koktová 1986: Koktová, E. Apposition as a Pragmatic Phenomenon in a Functional Description. Duisburg: Linguistic Agency University of Duisburg (Trier), June, 1986, Series A, Paper №158, pp. 1-34.

Kornilov 2012: Kornilov, N. V. Nereshennye voprosy teorii appozitivnyh sochetaniy. Vladimir: Izdatelystvo Vladimirskogo gosudarstvennogo universiteta [Корнилов, Н. В. Нерешенные вопросы теории аппозитивных сочетаний. Владимир: Издательство Владимирского государственного университета].

Kostov 1939: Kostov, N. Balgarska gramatika. Sofia: Knigoizdatelstvo „Kazanlashka dolina“ [Костов, Н. Българска граматика. София: Книгоиздателство „Казанльшка долина“"].

Krifka 1983: Krifka, M. Zur semantischen und pragmatischen Motivation syntaktischer Regularitäten: Eine Studie zur Wortstellung und Wortstellungsveränderung im Swahili. - In: Studien zur theoretischen Linguistik: Bd. 5. München: Wilhelm Fink.

Krotevich 1956: Krotevich, E. V. Sintaksicheskie otnoshenija mezhdu chlenami slovosochetanija i chlenami predlozhenija. // Voprosy russkogo yazykoznaniya, kn. 2, s. 3-18, Lyvov [Кротевич, Е. В. Синтаксические отношения между членами словосочетания и членами предложения. // Вопросы русского языкознания, кн. 2, с. 3-18, Львов].

Lehmann 1983: Lehmann, C. Rektion und syntaktische Relationen. - In: Köln: Inst. f. Sprachwiss. d. Univ. (akup, 45). Ersch. in Fol. Ling. 17. s. 339-378.

Lekant 1977: Lekant, P. A. Izuchenie struktury predlozheniya i slovosochetaniya v kurse sovremennogo russkogo yazyka. Moskva: MOPI, im. N. K. Krupskoy [Лекант, П. А. Изучение структуры предложения и словосочетания в курсе современного русского языка. Москва: МОПИ, им. Н. К. Крупской]. 
Lekant 2006: Lekant, P. A. Appozitivnoe slovosochetanie. - In: Kasatkin, L. L., E. V. Klobukov, P. A. Lekant. Kratkiy spravochnik po sovremennomu russkomu yazyku: Uchebnoe posobie. 3-e izd., ispr. i dop. Moskva: Vysshaya shkola, s. 297-298 [Лекант, П. А. Аппозитивное словосочетание. - В: Касаткин, Л. Л., Е. В. Клобуков, П. А. Лекант. Краткий справочник по современному русскому языку: Учебное пособие. 3-е изд., испр. и доп. Москва: Высшая школа, с. 297-298].

Lomov 2007: Lomov, A. M. Slovary-spravochnik po sintaksisu sovremennogo russkogo yazyka. Moskva: AST: Vostok - Zapad [Ломов, А. М. Словарьсправочник по синтаксису современного русского языка. Москва: АСТ: Восток - Запад].

Longrée 1987: Longrée, D. Les compléments du nom en Latin classique: syntaxe, sémantique et pragmatique. // Cahiers de l' Institut de Linguistique de Louvain 13: $163-230$.

Lyons 1977: Lyons, J. Semantics: Volume 1. Cambridge: Cambridge University Press.

Lyons 1995: Lyons, J. Linguistic Semantics. Cambridge: Cambridge University Press.

Malahov 2009: Malahov, A. S. Vidy grammaticheskoy svyazi v appozitivnyh sochetaniyah. Dissertaciya na soiskanie uchenoy stepeni kandidata filologicheskih nauk. Vladimir: Vladimirskiy gosudarstvennyy gumanitarnyy universitet [Малахов, А. С. Виды грамматической связи в аппозитивных сочетаниях. Диссертация на соискание ученой степени кандидата филологических наук. Владимир: Владимирский государственный гуманитарный университет] <http://109.74.206.116/files/3545c15c09eb 3ad27968a8731cacbc0f6b9b8fa8/4320270.pdf (status 14.08.2021)>.

Matezius 1967: Matezius, V. Jazyk i stily. - In: Prazhskiy lingvisticheskiy kruzhok. Sbornik statey. Moskva: Progress, s. 444-523 [Матезиус, В. Язык и стиль. - В: Пражский лингвистический кружок. Сборник статей. Москва: Прогресс, с. 444-523].

Matthews 1981: Matthews, P. H. Syntax. Cambridge: Cambridge University Press.

Matthews 2003: Matthews, P. H. The Concise Oxford Dictionary of Linguistics. Oxford University Press.

Matthews 2007: Matthews, P. H. Syntactic relations: A Critical survey. Cambridge: Cambridge University Press.

Merriam-Webster 1997: Merriam-Webster, inc. Webster's ninth new collegiate dictionary. Springfield, Mass., U.S.A.: Merriam-Webster.

Meyer 1992: Meyer, Ch. F. Apposition in Contemporary English. Cambridge; N. Y.: Cambridge University Press. (Studies in English Language. Ed. by Sidney Greenbaum et al.).

Mihnevich 1968: Mihnevich, A. E. Nekotorye voprosy izucheniya sintaksicheskih (podchinitelynyh) svyazey slov $\mathrm{v}$ rabotah sovetskih i chehoslovackih 


\section{Годииник на ФХH, XXXII A}

lingvistov. // Voprosy yazykoznaniya, 1968, № 5, s. 106-112. [Михневич, А. Е. Некоторые вопросы изучения синтаксических (подчинительных) связей слов в работах советских и чехословацких лингвистов. // Вопросы языкознания, 1968, № 5, с. 106-112].

Mishina 2007: Mishina, Ju. E. Prilozhenie v angliyskom yazyke. Samara: SGPU [Мишина, Ю. Е. Приложение в английском языке. Самара: СГПУ].

Moloshnaya 1975: Moloshnaya, T. N. Substantivnye slovosochetaniya v slavyanskih yazykah. Moskva: Nauka [Молошная, Т. Н. Субстантивные словосочетания в славянских языках. Москва: Наука].

Muhin 1974: Muhin, A. M. Appozitivnaya svyaz v strukture predlozheniy (na materiale russkogo yazyka). - In: Issledovaniya po slavyanskoy filologii. Moskva: Izd-vo MGU, s. 240-247 [Мухин, А. М. Аппозитивная связь в структуре предложений (на материале русского языка). - B: Исследования по славянской филологии. Москва: Изд-во МГУ].

Muratova 2018: Muratova, S. V. O statuse appozicionnyh struktur v sovremennom nemeckom yazyke. // Vestnik Kemerovskogo gosudarstvennogo universiteta, № 4, s. 240-246 [Муратова, С. В. О статусе аппозиционных структур в современном немецком языке. // Вестник Кемеровского государственного университета, № 4, с. 240-246].

Nehoroshkova 1989: Nehoroshkova, L. P. Prostranstvennye i vremennye appozitivnye konstrukcii v sovremennom angliyskom yazyke. Avtoref. dis. ... kand. filol. nauk. Moskva [Нехорошкова, Л. П. Пространственные и временные аппозитивные конструкции в современном английском языке. Автореф. дис. ... канд. филол. наук. Москва].

O'Connor 2008: O'Connor, K. M. Aspects de la syntaxe et de l'interprétation de l'apposition à antécédent nominal. $\mathrm{PhD}$ Dissertation, Université Charles de Gaulle, Lille 3.

OLD 1968: Oxford Latin Dictonary by P. G. W. Glare. London: Oxford University Press / Clarendon Press.

Orlov 1960: Orlov, K. P. Grammaticheskaya sushhnosty prilozheniya v sovremennom russkom literaturnom yazyke. // Filologicheskie nauki, № 4, s. 29-37 [Орлов, К. П. Грамматическая сущность приложения в современном русском литературном языке. // Филологические науки, № 4, c. 29-37].

Osenova 2009: Osenova, P. Imennite frazi v balgarskiya ezik. Sofia: „ETO“ [Осенова, П. Именните фрази в българския език. София: „ЕТО“].

Peshkovskiy 2001: Peshkovskiy, A. M. Russkiy sintaksis v nauchnom osveshhenii, 8-e izd., dop. Moskva: Jazyki slavyanskoj kulytury [Пешковский, А. М. Русский синтаксис в научном освещении, 8-е изд., доп. Москва: Языки славянской культуры]. 
Peterson 1999: Peterson, P. On the boundaries of syntax. - In: The Clause in English. In Honour of Rodney Huddleston. P. Collins \& D. Lee (eds.). Amsterdam: John Benjamins, pp. 229-250.

Popov 1942: Popov, D. Balgarska gramatika. Sofia: Knigoizdatelstvo „Hristo G. Danov“ [Попов, Д. Българска граматика. София: Книгоиздателство „Христо Г. Дановь“].

Popov 1978: Popov, K. Strukturni, semantichni i funktsionalni osobenosti na apozitsiyata (prilozhenieto) v balgarskia i sarboharvatskia ezik. // Slavyanska filologia. Tom HV. Sofia: UI „Sv. Kliment Ohridski“, s. 207-218 [Попов, К. Структурни, семантични и функционални особености на апозицията (приложението) в българския и сърбохърватския език. // Славянска филология. Том XV. София: УИ „Св. Климент Охридски“, с. 207-218].

Potebnya 1958: Potebnya, A. A. Iz zapisok po russkoy grammatike. T. I - II, Moskva: Uchpedgiz [Потебня, А. А. Из записок по русской грамматике. T. I - II, Москва: Учпедгиз] <http://elib.gnpbu.ru/text/potebnya iz-zapisok-porusskoy-grammatike_t1-2_1958/go,110;fs,1/(status 6.08.2021) >.

Potts 2005: Potts, C. The logic of Conventional Implicatures. New York: Oxford University Press.

Priyatkina 2007: Priyatkina A. F. O vzaimnom otnoshenie vidov sintaksicheskoy svyazi. - In: Priyatkina, A. F. Russkiy sintaksis v grammaticheskom aspekte (sintaksicheskie svyazi i konstrukcii). Izbrannye trudy. Vladivostok: Izd-vo Dalynevostochnogo universiteta, s. 18-27 [Прияткина А. Ф. О взаимном отношение видов синтаксической связи. - В: Прияткина, А. Ф. Русский синтаксис в грамматическом аспекте (синтаксические связи и конструкции). Избранные труды. Владивосток: Изд-во Дальневосточного университета, с. 18-27].

Puleha 1999: Puleha, I. R. Prilozhenie v sovremennom angliyskom yazyke: dis. ... kand. filol. nauk. Sankt Peterburg [Пулеха, И. Р. Приложение в современном английском языке: дис. ... канд. филол. наук. Санкт Петербург].

Quirk et al. 1985: Quirk, R., Greenbaum, S., Leech, G., Svartvic, J. A Comprehensive Grammar of the English Language. London; New York: Longman.

Quirk, Greenbaum 1991: Quirk, R., S. Greenbaum. A University Grammar of English. Harlow (Ess.): Longman.

Raabe 1979: Raabe, H. Apposition. Untersuchungen zu Begriff und Struktur. Tübingen: Gunter Narr Verlag.

RCHDBE 1992: Rechnik na chuzhdite dumi v balgarskiya ezik. Sofia: Izdatelstvo na BAN [Речник на чуждите думи в българския език. София: Издателство на БАН]. 


\section{Годииник на ФХН, XXXII $A$}

Ries 1928: Ries, J. Zur Wortgruppenlehre: mit Proben aus einer ausführlichen Wortgruppenlehre der deutschen Sprache der Gegenwart. Prag: Taussig \& Taussig.

Roberts 1962: Roberts, P. English Sentences. New York: Harcourt, Brace and World.

Rudnev 1959: Rudnev, A. G. Obosoblennye chleny predlozheniya v istorii russkogo yazyka. // Uch. zapiski LGPI im. A. I. Gercena. T. 174 [Руднев, А. Г. Обособленные члены предложения в истории русского языка. // Уч. записки ЛГПИ им. А. И. Герцена].

Rudnev 1963: Rudnev, A. G. Sintaksis sovremennogo russkogo yazyka. Moskva: Vysshaya shkola [Руднев, А. Г. Синтаксис современного русского языка. Москва: Высшая школа].

Schindler 1990: Schindler, W. Untersuchungen zur Grammatik appositionsverdächtiger Einheiten im Deutschen. Tübingen: Max Niemeyer Verlag.

Seright 1966: Seright, O. D. On Defining the Appositive. // College Composition and Communication, Vol. 17, No. 2 (May, 1966), pp. 107-109.

Severyyanova 1978: Severyyanova, V. A. Prilozhenie v sovremennom angliyskom yazyke: Avtoref. dis. ... kand. filol. nauk. Leningrad [Северьянова, В. А. Приложение в современном английском языке: Автореф. дис. ... канд. филол. наук. Ленинград].

Shahmatov 2001: Shahmatov, A. A. Sintaksis russkogo yazyka. Moskva: Uchpedgiz [Шахматов, А. А. Синтаксис русского языка. Москва: Учпедгиз].

Shatuh 1954: Shatuh, M. G. Prilozhenie i ego roly v sovremennom russkom yazyke: Avtoref. dis. ... kand. filol. nauk. Lyvov [Шатух, М. Г. Приложение и его роль в современном русском языке: Автореф. дис. ... канд. филол. наук. Львов].

Silvestre de Sacy 1822: Silvestre de Sacy, A. I. Principes de grammaire générale: mis à la portée des enfans, et propres à servir d'introduction à l'étude de toutes les langues. Quatriéme édition. Revue et corrigée. Paris: Chez Delance et Lesureur.

Sinclair 1972: Sinclair, J. McH. A Course in Spoken English: Grammar. London: Oxford University Press.

Sopher 1971: Sopher, H. Apposition. // English Studies 52, pp. 401-412.

Sowinski 1991: Sowinski B. Deutsche Stilistik. Beobachtungen zur Sprachverwendung und Sprachgestaltung im Deutschen. Berlin, Deutschland: Fischer Taschenbuch Verlag GmbH.

Starodumova 2005: Starodumova, E. A. Sintaksis sovremennogo russkogo yazyka. Vladivostok: Izdatelystvo Dalynevostochnogo gosudarstvennogo universiteta [Стародумова, Е. А. Синтаксис современного русского языка. Владивосток: Издательство Дальневосточного государственного университета] <http://window.edu.ru/resource/025/41025/files/dvgu146.pdf (status 6.08.2021)>. 
Stevens 1993: Stevens, C. M. Untersuchungen zur Grammatik appositionsverdächtiger Einheiten im Deutchen. Wolfgang Schindler. Tübingen: Max Niemeyer, 1990. // American Journal of Germanic Linguistics and Literatures, 4 (2), pp. 181-188.

Sturm 1986: Sturm, A. N. Primaire syntactische structuren in het Nederlands. Leiden: Nijhoff. PhD Dissertation, University of Nijmegen.

Taboada 1978: Taboada, $M$. Relaciones sintácticas en el interior de la frase nominal: la aposición. // Verba. Anuario Galego de Filoloxía, vol. 5, (1978), pp. 315 340.

Taylor 2002: Taylor, J. R. Cognitive grammar. Oxford: Oxford University Press.

Teodorov-Balan 1940: Teodorov-Balan, Al. Nova balgarska gramatika. Sofia: Knigoizdatelstvo „T. F. Chipev“ [Теодоров-Балан, Ал. Нова българска граматика. София: Книгоиздателство „Т. Ф. Чипев“].

Tesnière 1969: Tesnière, L. Les Éléments de syntaxe structurale. Paris: Klincksieck.

Trask 1996: Trask, R. L. A Dictionary of Grammatical Terms in Linguistics. London: Routledge.

Uhanov 1974: Uhanov, G. P. Poyasnitelynaya svyazy v eyo otnoshenii k sochineniyu i podchineniyu. - In: Issledovaniya po slavyanskoy filologii. Moskva: Izd-vo MGU, s. 336-342 [Уханов, Г. П. Пояснительная связь в её отношении к сочинению и подчинению. - В: Исследования по славянской филологии. Москва: Изд-во МГУ, с. 336-342].

Vaceba 1973: Vaceba, R. V. K voprosu ob appozitivnoy svyazi. - In: Problemy teorii chlenov predlozheniya. Kishinev: Izd-vo Shtiinca, s. 154-160 [Вацеба, Р. В. К вопросу об аппозитивной связи. - В: Проблемы теории членов предложения. Кишинёв: Изд-во Штиинца, с. 154-160].

Watt 1964: Watt, W. W. An American Rhetoric. Holt, Rinehart and Winston, Inc.; Third Edition.

Weinrich 1993: Weinrich, H. Textgrammatik der deutschen Sprache. Mannheim; Leipzig; Wien; Zürich: Duden-Verlag.

Wright, Budin 1997: Wright, S. E., G. Budin (eds.). Handbook of Terminology Management: Basic Aspects of Terminology Management. Amsterdam and Philadelphia: John Benjamins.

Wykoff, Shaw 1952: Wykoff, G. S., H. Shaw. The Harper Handbook of College Composition: Harper \& Brothers; Reprint edition.

Zaharenko 1998: Zaharenko, E. K. Strukturno-semanticheskie tipy appozitivov i ih funkcionirovanie v sovremennom angliyskom yazyke: Avtoref. dis. ... kand. filol. nauk. MGLU. Moskva: B. i. [Захаренко, Е. К. Структурносемантические типы аппозитивов и их функционирование в современном английском языке: Автореф. дис. ... канд. филол. наук. МГЛУ. Москва: Б. и.].

Zemb 1968: Zemb, J. M. Les structures logiques de la proposition allemande. Paris: OCDL. 